\title{
The benefit of a preoperative respiratory protocol and musculoskeletal exercise in patients undergoing cardiac surgery
}

\author{
Paolo Nardi ${ }^{1}$, Calogera Pisano ${ }^{1}$, Claudia Altieri ${ }^{1}$, Dario Buioni ${ }^{1}$, Carlo Pedicelli ${ }^{2}$, Silvia Saulle ${ }^{3}$, \\ Romana Dandi ${ }^{3}$, Alessia Romano ${ }^{3}$, Annamaria Servadio ${ }^{4}$, Alessandra Gianlorenzi ${ }^{5}$, Katia Emili ${ }^{5}$, Giovanni Ruvolo ${ }^{1}$ \\ ${ }^{1}$ Cardiac Surgery Division, Tor Vergata University Hospital, Rome, Italy \\ 2Degree of Physiotherapy, Tor Vergata University Hospital, Rome, Italy \\ ${ }^{3}$ Physiotherapy Service, Tor Vergata University Hospital, Rome, Italy \\ ${ }^{4}$ Management Coordinator Rehabilitation Area, Tor Vergata University Hospital, Rome, Italy \\ ${ }^{5}$ Management Coordinator Cardiac Surgery Division, Tor Vergata University Hospital, Rome, Italy
}

Kardiochir Torakochir Pol 2020; 17 (2): 94-100

\begin{abstract}
Introduction: Loss of physical activity and pulmonary dysfunction with its associated complications represent two of the most important causes of morbidity and mortality following cardiac surgery.

Aim: To evaluate whether a physiotherapy program based on respiratory training with or without musculoskeletal mobilization, started preoperatively, may provide a significant improvement in pulmonary and musculoskeletal recovery postoperatively in a sufficiently large sample of patients undergoing elective cardiac surgery.

Material and methods: One-hundred and two patients with similar baseline and preoperative characteristics were assigned to a preoperative respiratory physiotherapy protocol (group $\mathrm{R}, n=34$ ), a preoperative respiratory and motor physiotherapy protocol (group $\mathrm{R}+M, n=34$ ), or no preoperative specific physiotherapy protocol but only a simplified perioperative standard physiotherapy protocol (control group, C, $n=34$ ). Data on 6-minute walking test, peak expiratory flow, and from blood gas analysis were retrospectively analyzed.

Results: As compared with group C, a statistically significant improvement was observed in the two preoperatively treated groups in terms of 1$)$ better pre- $(+0.7-0.8 \mathrm{Lt} / \mathrm{min}, p<0.05)$ and postoperative $(+1 \mathrm{Lt} / \mathrm{min}, p<0.01)$ peak expiratory flow values; 2$)$ longer pre- $(+50-100 \mathrm{~m}, p<0.01)$ and postoperative (+65-170 m, $p<0.01$ ) distance traveled in the 6-minute walking test; 3 ) better $\mathrm{PaO}_{2}, \mathrm{SaO}_{2}, \mathrm{pH}$ value in postoperative blood gas measurements ( $p<0.05$, for all comparisons); 4 ) reduction of postoperative length of in-hospital stay $(p<0.05)$.

Conclusions: A benefit of combined respiratory and motor physiotherapy protocols can be expected in the groups of patients preoperatively treated, especially with the respiratory one, either before or after cardiac surgery with a faster recovery of physical-functional activities. Specifically, the motor pro-
\end{abstract}

\section{Streszczenie}

Wprowadzenie: Utrata aktywności fizycznej i upośledzenie czynności płuc wraz z towarzyszącymi im powikłaniami stanowią dwie główne przyczyny zachorowań i śmiertelności po operacjach kardiochirurgicznych.

Cel pracy: Ustalenie, czy wdrożony przedoperacyjnie program fizjoterapii z treningiem oddechowym i mobilizacją układu mięśniowo-szkieletowego lub bez mobilizacji pozwala uzyskać istotną pooperacyjną poprawę czynności płuc i układu mięśniowo-szkieletowego w wystarczająco dużej grupie pacjentów poddanych planowej operacji kardiochirurgicznej.

Materiał i metody: Stu dwóch pacjentów o podobnej charakterystyce wyjściowej i przedoperacyjnej przypisano do grupy, w której stosowano przedoperacyjny protokół fizjoterapii oddechowej (grupa $\mathrm{R}, n=34$ ), przedoperacyjny protokół fizjoterapii oddechowej i ruchowej (grupa $\mathrm{R}+\mathrm{M}, n=34$ ) lub grupy, w której nie wdrożono specjalnego przedoperacyjnego protokołu fizjoterapeutycznego, a jedynie uproszczony standardowy protokół fizjoterapii okołooperacyjnej (grupa kontrolna $C, n=34$ ). Retrospektywnie przeanalizowano dane z testu 6-minutowego marszu, wyniki pomiaru szczytowego przepływu wydechowego i gazometrii.

Wyniki: W porównaniu z grupą C w dwóch grupach poddanych protokołowi przedoperacyjnemu stwierdzono statystycznie istotną poprawę pod względem: 1) korzystniejszych przed$(+0,7-0,8 \mathrm{l} / \mathrm{min}, p<0,05)$ i pooperacyjnych wartości szczytowego przepływu wydechowego (+1 l/min, $p<0,01)$; 2) dłuższego odcinka pokonanego przez pacjentów w przed- $(+50-100 \mathrm{~m}$, $p<0,01)$ i pooperacyjnym teście 6-minutowego marszu (+65-170 m, $p<0,01)$; 3) korzystniejszych wartości $\mathrm{PaO}_{2}, \mathrm{SaO}_{2}$ i pH w pooperacyjnym badaniu gazometrycznym $\mathrm{krwi}(p<0,05$ dla wszystkich porównań); 4) skrócenia długości pooperacyjnego pobytu w szpitalu $(p<0,05)$.

Wnioski: W grupach pacjentów, w których przed zabiegiem kardiochirurgicznym stosowany jest protokół fizjoterapii odde-

Address for correspondence: Paolo Nardi MD, PhD, Tor Vergata University Hospital, Viale Oxford 81, 00133 Rome, Italy, phone: +39 (06)20903584, fax: + 39 (06)20903538, e-mail: pa.nardi4@libero.it

Received: 6.02.2020, accepted: 9.06.2020. 
tocol is associated with greater autonomy of running before or after cardiac surgery.

Key words: respiratory protocol, cardiac surgery, musculoskeletal exercise.

\section{Introduction}

In any major surgery, such as cardio-thoracic surgery, the prevention of postoperative pulmonary complications is relevant, as they are strongly associated with increased morbidity and mortality. In cardiac surgery, the impairment of pulmonary function has several causes, including sternotomy to perform cardiopulmonary bypass, pleurotomy for the harvesting of the internal mammary artery as a graft for coronary artery bypass surgery, pleural drain insertion, and dysfunction of the phrenic nerve due to the use of cold cardioplegic solutions [1-4]. Perioperative rehabilitation protocols, aimed to maintain an adequate lung function and allow a faster postoperative mobilization, can be very important to reduce postoperative complications related to immobilization and therefore to lead towards a more rapid recovery after cardiac surgery [5-7].

While postoperative rehabilitation programs following cardiac surgery have been shown to improve short-term outcomes, few studies have investigated the effects of preoperative interventions targeted at improving cardiorespiratory and musculoskeletal function in the postoperative period. In particular, the aim of a physiotherapy protocol should be to restore preoperative physical functional capacity, through prescription of walking exercise and thoracic mobility and respiratory exercises. In a previous published work, in a quite small sample of patients subjected to an elective cardiac operation, we observed a better clinical early outcome in patients treated preoperatively with an expiratory and muscle physiotherapy protocol in comparison with a control group [8].

\section{Aim}

The purpose of this study was to evaluate whether the proposed physiotherapy treatment started in the preoperative phase and based on respiratory training with or without musculoskeletal exercise may provide a significant improvement of postoperative pulmonary and musculoskeletal recovery, and consequently a reduction of in-hospital stay in a larger group of patients undergoing elective cardiac surgery. The results obtained from the groups of patients treated by means of the physiotherapy protocols were assessed and compared with those observed in the control group.

\section{Material and methods}

The experimental investigation was carried out at the Cardiac Surgery Unit of the Tor Vergata University Hospital chowej i ruchowej, zwłaszcza trening oddechowy, można oczekiwać korzyści przed zabiegiem lub po zabiegu w postaci szybszego powrotu sprawności fizycznej i czynnościowej. Zwłaszcza protokót fizjoterapii ruchowej wiąże się z większą sprawnością ruchową przed zabiegiem lub po zabiegu kardiochirurgicznym.

Słowa kluczowe: protokół oddechowy, operacja kardiochirurgiczna, ćwiczenia układu mięśniowo-szkieletowego.

of Rome. The study took place during a period of 18 months and the initial 65-patient study was extended to one-hundred and two patients (mean age of $64 \pm 10$ years). The study was approved by the Institutional Review Board of the Tor Vergata University Hospital, which waived the need for patient consent. The study was designed as a retrospective one. All patients gave their consent to the proposed protocol with the signature in the medical record and then gave consent to the surgical intervention.

\section{Groups of analyzed patients}

The study considered two groups of patients (group R, respiratory physiotherapy protocol, $n=34$, and group $R+M$, respiratory and motor physiotherapy protocols, $n=34$ ) treated preoperatively and postoperatively, and a control group of patients (group C, $n=34$ ) treated with a simplified physiotherapy standard respiratory protocol and walking protocol, in order to avoid complications related to the absence of movement.

\section{Enrollment criteria}

Inclusion criteria adopted to enroll the patients in the study were chronic obstructive pulmonary disease with NYHA class I, II, III, good exercise tolerance at the time of in-hospital admission, and chance to take benefit from respiratory and motor treatment. In particular, even patients with NYHA class III reported in their history, but deemed able to perform the exercise protocols, carried out the study protocol, obviously always under the control of the doctor during the exercises, especially the 6-minute walking test.

Exclusion criteria were the presence of NYHA class IV, patients on dialysis treatment or affected by neurological dysfunction and unable to understand the physiotherapist's indications, patients affected by disabling osteoarticular muscle diseases, acute coronary syndromes, and cardiac diseases requiring emergency surgery.

As previously reported, the physiotherapy treatment consisted of three phases: preoperative treatment in the cardiac surgery department, postoperative treatment in the intensive care unit, and postoperative treatment in the cardiac surgery department. Patients were instructed on exercises to be done by the physiotherapist. All breathing and muscle exercises were performed by each patient individually in the presence of the physiotherapist, under the supervision of the physician. 


\section{Data collection}

The 6-minute walking test (6MWT) was performed in all three groups of patients the day before cardiac surgery and the last day before discharge from the hospital. The $6 \mathrm{MWT}$ was conducted according to standard protocols, using a corridor with a length of $25 \mathrm{~m}$ bounded by a colored ribbon on the floor. The patients had the opportunity to stop or take breaks during the test, but at the same time they were asked to start walking again as soon as possible [9]. A stopwatch was used to keep the time of 6 minutes. Before the beginning of the walk and at the end of the 6 minutes, a Borg scale was assigned to indicate the degree of breathlessness, in terms of dyspnea, chest pain, confusion, or leg pain on a scale of 0 (nothing) to 10 (severe) [10]. All patients underwent the peak expiratory flow (PEF) examination, i.e. the highest expiratory flow obtained during a forced expiratory maneuver performed immediately after a maximal inhalation. In the two groups of patients, $R$ and $R+M$, the PEF test was performed after the respiratory treatment protocol; 6MWT and PEF examination tests were performed in all cases before the meal.

At the initial admission and on the last day of postoperative treatment, an arterial blood sample was taken and blood gas analysis was performed before the meal in all patients, through which it was possible to observe changes and differences in cardiorespiratory function following surgery and physiotherapy protocols. The parameters taken into consideration were values of $\mathrm{pH}$, partial arterial pressure of carbon dioxide $\left(\mathrm{PaCO}_{2}\right)$, partial arterial pressure of oxygen $\left(\mathrm{PaO}_{2}\right)$, arterial oxygen saturation $\left(\mathrm{SAO}_{2}\right)$, concentration of hemoglobin and concentration of bicarbonate ions $\left(\mathrm{HCO}_{3}{ }^{-}\right)$.

\section{Physiotherapy protocols adopted in the two groups of patients}

In the preoperative phase, patients were informed about the importance of early mobilization carried out in the following 24 hours, of keeping the seated position in the chair, followed by the standing station and walking, in order to favor the physiological re-expansion of the lungs. These protocols were used in the subjects belonging to both groups $R$ and $R+M$. In particular, patients of both groups learned deep breathing exercises through long and deep current volume breaths, to maintain a short apnea and to perform one or two coughing strokes followed by a slow and gentle exhalation with half-closed lips. Thoracic and abdominal breathing were taught to mobilize different lung areas in order to obtain better lung ventilation, and the use of volume and flow incentive was taught to promote deep inhalation training with an open glottis (aimed at lung parenchymal re-expansion). Finally, patients learned the positive exhalation pressure (PEP) technique using a PEP bottle to facilitate bronchial drainage and to prevent atelectasis $[11,12]$.

Patients of $R$ and $R+M$ groups underwent the same following respiratory treatment: 1 . Keeping their hands on their abdomen, a) inhaling from the nose using abdominal muscles, b) exhaling by blowing from the mouth. 2. Keeping their hands resting on the upper part of their thorax, a) inhaling from the nose using chest muscles, b) exhaling from the mouth. 3. Keeping their hands on their chest, a) inhaling keeping their arms outstretched, b) exhaling bringing their hands back to their chest. 4. Putting their hands on their chest, a) inhaling keeping their arms outstretched, b) exhaling bringing their hands back to their chest. 5. Keeping their hands on their chest a) inhaling with their arms outstretched upwards, b) exhaling bringing their hands back to their chest. 6 . Keeping their arms along sides, a) inhaling bringing their arms forward and up, b) exhaling bringing their arms back out and down along sides. 7. Keeping their hands behind their nape with elbows forward, a) breathing expanding their elbows, b) exhaling closing their elbows. 8. Keeping their hands on their hips, a) inhaling, b) exhaling by rotating their trunk to the right, c) inhaling, d) exhaling by rotating their trunk to the left.

Groups $R$ and $R+M$ were taught to use the expiratory flow to mobilize bronchial secretions, in order to achieve the highest possible expiratory flow rate in the bronchi, without performing a forced expiration, but by regulating the force with which exhalation takes place.

Patients of the $R+M$ group also performed active movements of their upper and lower limbs, with muscle stretching and relaxation. The exercises were performed in bed and in a standing position, including 1. Passive and active assisted mobilization of their four limbs against variable resistance; the mobilization against resistance was performed at low load and assisted by the physiotherapist. 2. Flexion of their knees to the chest by accompanying flexion with their hands. 3. Bending their legs without raising their heels, and back. 4. Moving a limb backwards with an extended knee and bending the supporting leg. 5. Extension of the hip with an extended knee. 6 . Lifting their heels from the ground. 7. Extension of their knee with the foot flexed dorsally, and back. 8. Raising one leg, bending the knee and crossing it on the other leg. 9. Abduction and adduction of their legs. 10. Flexion and extension of their limbs for 1 minute. 11. Go up and down small steps. 12. Extension of their arms up and back with hands on their shoulders. 13. Eight small rotations of the arms for two minutes forward and back. 14. Torsion of their trunk from one side to the other.

Group C patients in this phase performed a standard preoperative preparation, consisting of breathing exercises of the chest and abdomen with associated postural passages up to assisted walking.

In the postoperative intensive care unit, the aim of physiotherapy for all the three groups of patients was early mobilization associated with the stimulation of thoracic and abdominal breathing in order to accelerate the delicate phases of awakening and weaning from the mechanical ventilation. Treatment consisting in assisted active-passive mobilization, assisted cough, slight postural changes, and breathing exercises was performed daily for all the patients.

In the ward, patients of $R$ and $R+M$ groups performed respiratory exercises with or without motor exercises as in- 
dicated during the period of education of the preoperative phase, progressively from the first to the sixth day up to the achievement of complete respiratory and motor autonomy. Patients of the control group were only helped in postural passages and assisted walking, and their clinical conditions were assessed daily.

\section{Statistical analysis}

Statistical analysis was performed with the Stat View 4.5 program (SAS Institute Inc, Abacus Concepts, Berkeley, CA, USA). Student's $t$ test was used to analyze continuous data, the $\chi^{2}$ or Fisher's exact test to analyze categorical data. Several variables were selected and compared, including age, gender, smoking habit, co-morbidities (arterial hypertension, diabetes mellitus, chronic obstructive pulmonary disease, hyperlipidemia, obesity), New York Heart Association class (NYHA), body mass index, blood gas analyzed values $\left(\mathrm{pH}, \mathrm{PaO}_{2}, \mathrm{PaCO}_{2}, \mathrm{SAO}_{2}\right.$, hemoglobin level, $\mathrm{HCO}_{3}^{-}$), PEF, 6MWT, and length of in-hospital stay. Intraoperative surgical assessed in this study were the duration of intervention, i.e. cardiopulmonary bypass and aortic cross-clamp times, type of procedure, i.e. coronary artery bypass surgery, heart valves procedures, and aortic aneurysm replacement techniques. All continuous variables were expressed as mean values plus or minus one standard deviation of the mean. $P$-values less than 0.05 were considered statistically significant.

\section{Results}

All three groups of patients had similar baseline demographic and preoperative clinical characteristics, except for higher incidence of active smokers in groups $R+M$ and $R$ in comparison with group $C$, and similar surgical variables, i.e. type of surgical procedures, mean duration of surgery (Table I). Preoperative blood gas analysis showed similar values of $\mathrm{pH}, \mathrm{PaCO}_{2}, \mathrm{PaO}_{2}, \mathrm{SAO}_{2}$, hemoglobin level, and bicarbonate ion concentration in all three groups of patients ( $p=$ not significant, for all comparisons).

Preoperative and postoperative PEF values were significantly better in the two groups of treated patients, $R$ and $R$ $+M$, in comparison with group $C$ (Tables II, III). In particular, the best results were obtained in the postoperative period, with a strong statistical significance in both groups treated with the same respiratory protocol (Table III).

In the same way, preoperatively and postoperatively, in the $6 \mathrm{MWT}$, both groups $\mathrm{R}$ and $\mathrm{R}+\mathrm{M}$ achieved a significantly higher running autonomy expressed in meters traveled as compared with the untreated group C (Tables IV, V). In the postoperative period the temporary decrease in motor activity related, as expected, to the surgical intervention, was lower in the two treated groups in comparison with group C. Of note, as shown in Table $V$, group $R+M$ obtained the best results, both in the pre- and postoperative period, and also when compared to group $\mathrm{R}$; in particular, the decrease in meters traveled in the postoperative period in comparison with the preoperative period between the three groups was markedly in favor of group $\mathrm{R}+\mathrm{M}$.

At discharge, the mean value of $\mathrm{PaO}_{2}$ in ambient air was significantly higher in group $\mathrm{R}$ in comparison with group C (76.7 \pm 13 vs. $67.7 \pm 12 \mathrm{~mm} \mathrm{Hg}, p<0.01)$. The mean value of $\mathrm{O}_{2}$ arterial saturation was significantly higher in both groups, $R$ and $R+M$, in comparison with group $C$

Table I. Patient population characteristics

\begin{tabular}{|c|c|c|c|c|}
\hline Variable & $\begin{array}{l}\text { Group R } \\
(n=34)\end{array}$ & $\begin{array}{l}\text { Group } R+M \\
(n=34)\end{array}$ & $\begin{array}{l}\text { Group C } \\
(n=34)\end{array}$ & $P$-value \\
\hline Male/female, $n$ & $25 / 9$ & $12 / 22$ & $25 / 9$ & 0.654 \\
\hline Age (mean \pm SD) [years] & $64.3 \pm 8.7$ & $64.2 \pm 16.3$ & $66.2 \pm 12.1$ & NS \\
\hline NYHA class (mean \pm SD) & $2.0 \pm 0.8$ & $2.0 \pm 0.8$ & $2.4 \pm 0.7$ & NS \\
\hline BMI (mean \pm SD) & $30.5 \pm 2.1$ & $28.3 \pm 6.1$ & $28.3 \pm 4.1$ & NS \\
\hline Hypertension, $n$ (\%) & $18(53)$ & $18(53)$ & $26(76)$ & 0.071 \\
\hline Diabetes, $n(\%)$ & $12(35)$ & $9(26)$ & $5(15)$ & 0.148 \\
\hline Dyslipidemia, $n$ (\%) & $10(29)$ & $14(41)$ & $11(32)$ & 0.568 \\
\hline Obesity, $n(\%)$ & $7(21)$ & $3(8.9)$ & $5(15)$ & 0.391 \\
\hline Active smokers, $n(\%)$ & $6(18)$ & $11(32)$ & $3(8.9)$ & 0.045 \\
\hline Previous smokers, $n(\%)$ & $10(29)$ & $8(24)$ & $18(53)$ & 0.027 \\
\hline \multicolumn{5}{|l|}{ Surgical procedures, n (\%): } \\
\hline Ascending aorta replacement & $6(18)$ & $4(12)$ & $7(21)$ & 0.610 \\
\hline Aortic valve replacement & $13(38)$ & $12(35)$ & $15(44)$ & 0.749 \\
\hline Mitral valve replacement & $6(18)$ & $5(15)$ & $4(12)$ & 0.790 \\
\hline Coronary artery bypass grafting & $9(26)$ & $13(38)$ & $8(24)$ & 0.545 \\
\hline Operative time (mean \pm SD) [min] & $266.41 \pm 85.8$ & $279.18 \pm 74.4$ & $282.2 \pm 70.8$ & NS \\
\hline CPB time (mean \pm SD) $[\mathrm{min}]$ & $103.85 \pm 40.9$ & $119.82 \pm 54.7$ & $121.62 \pm 49.1$ & NS \\
\hline Aortic clamp time (mean \pm SD) $[\mathrm{min}]$ & $81.94 \pm 34.9$ & $92.50 \pm 41.47$ & $94.32 \pm 40.8$ & NS \\
\hline
\end{tabular}

BMI - body mass index, NYHA - New York Heart Association, CPB - cardiopulmonary bypass, SD - standard deviation, NS - not significant, for all comparisons. 
Table II. Preoperative peak expiratory flow (PEF) values (l/min)

\begin{tabular}{lccc}
$\begin{array}{l}\text { Group R } \\
(n=34)\end{array}$ & $\begin{array}{c}\text { Group R }+M \\
(n=34)\end{array}$ & $\begin{array}{c}\text { Group C } \\
(n=34)\end{array}$ & $\begin{array}{l}P \text {-value } \\
3.27 \pm 1.46\end{array}$ \\
\hline & $3.24 \pm 1.38$ & $2.52 \pm 1.31$ & $0.925^{*}$ \\
\hline & & $0.031^{\star *}$ \\
\hline
\end{tabular}

${ }^{\star} P=$ not significant (group R vs. group $R+M$ ); ${ }^{* *} p=$ significant (group R vs. group $C$ ); ${ }^{* \star *} p=$ significant (group $R+M$ vs. group $C$ ).

Table III. Postoperative peak expiratory flow (PEF) values (l/min)

\begin{tabular}{lccc}
$\begin{array}{l}\text { Group R } \\
(n=34)\end{array}$ & $\begin{array}{c}\text { Group R + M } \\
(n=34)\end{array}$ & $\begin{array}{c}\text { Group C } \\
(n=34)\end{array}$ & P-value \\
$2.65 \pm 1.38$ & $2.63 \pm 1.24$ & $1.58 \pm 0.84$ & $0.964^{\star}$ \\
\hline & & $0.003^{\star *}$ \\
\hline & & $0.0001^{\star * *}$ \\
\hline
\end{tabular}

${ }^{*} P=$ not significant (group R vs. group $R+M$ ); ${ }^{* *} p=$ significant (group R vs. group C); ${ }^{* \star *} p=$ significant (group $R+M$ vs. group $C$ ).

Table IV. Preoperative 6-minute walking test values (6MWT) $(\mathrm{m})$

\begin{tabular}{lccc}
$\begin{array}{l}\text { Group R } \\
(n=34)\end{array}$ & $\begin{array}{c}\text { Group R }+M \\
(n=34)\end{array}$ & $\begin{array}{c}\text { Group C } \\
(n=34)\end{array}$ & P-value \\
$348.7 \pm 96.1$ & $415.3 \pm 90.7$ & $299.7 \pm 96.3$ & $0.004^{*}$ \\
\hline & & $0.039^{* *}$ \\
\hline
\end{tabular}

${ }^{\star} P=$ significant (group R vs. group $\mathrm{R}+\mathrm{M}$ ); ${ }^{* *} p=$ significant (group $\mathrm{R}$ vs. group $\mathrm{C}$ ); ${ }^{\star * *} p=$ significant (group $R+M$ vs. control group).

(98 $\pm 1.2 \%$ and $97.0 \pm 1.5 \%$ vs. $96.0 \pm 2.0 \%, p \leq 0.001$, for both comparisons) (Figure 1). Testimony to a better respiratory balance obtained through the physiotherapy protocol in the two groups treated was also the $\mathrm{pH}$ value, which was within the limits of the norm with respect to the control group, which showed slight alkalotic hyperventilation (7.47 and 7.48 vs $7.5 \mathrm{pH}$-value. $p<0.05$, for both comparisons).

The incidence of pulmonary complications was $2.9 \%$ in group $\mathrm{R}$ (one case, primary respiratory distress requiring reintubation), absent in group $R+M$, and $5.8 \%$ in the control group (one case, pleural effusion requiring drainage; the other case, infection requiring antibiotic therapy). As compared with the control group, groups $R$ and $M+R$ showed a significantly shorter postoperative length of in-hospital stay ( $7.0 \pm 1.2$ and $9.4 \pm 3.5$ days vs. $12.4 \pm 7.9$ days) $(p<0.05$, for both comparisons).

\section{Discussion}

Patients undergoing cardiac surgery may have postoperative functional impairment significantly compromising their recovery capacity and level of autonomy and generally leading to pulmonary dysfunction and to reduced tolerance to exercise related to sternotomy, to cardiopulmonary bypass and reduced physical activity $[13,14]$. The benefits of post-surgical rehabilitation have been well documented; however, less is known about the role that a preoperative rehabilitation protocol may have on the postoperative outcome of patients undergoing cardiac surgery [15-19].

In a study previously published we aimed to investigate how a preoperative training protocol applied on a quite small sample of patients, based on the increase of respiratory capacity, muscle strength and exercise tolerance, could reduce the expected functional decrease observed in patients undergoing cardiac surgery [8]. By comparing the three groups examined, it was possible to highlight better physical and respiratory conditions in patients of the two groups treated preoperatively in comparison with the control group, either before cardiac surgery or in the postoperative period. From the data that emerged in the current study carried out in a larger group of patients, we observed that respiratory treatment and muscular exercise have undoubtedly conferred important advantages as regards to the respiratory function itself, to a greater recovery of motor function and therefore of greater respiratory-muscular autonomy, and reduced postoperative stay. In particular, the physiotherapeutic respiratory protocol adopted in the two groups of patients allowed a gain of at least $1 \mathrm{l} /$ minute following the full sternotomy in comparison with the control group, and favored, independently of the muscle protocol used in only one group, a greater motor autonomy, before and after surgery (Tables III-V). However, the motor protocol applied in the $R+M$ group was associated "in itself" with greater autonomy of travel both before and after cardiac surgery (Tables IV, V).

The respiratory protocol in both groups of treated patients conferred a better balance of the $\mathrm{pH}$ value. Similarly, the reduction in $\mathrm{PaO}_{2}$ and $\mathrm{SaO}_{2}$ values observed after surgery in comparison with the preoperative period was not statistically significant in the two groups of patients treated by means of the respiratory protocol, while in the control group a more marked postoperative reduction was detected, with statistical significance (Figure 1).

The main finding that we observed in this specific study was that of the two protocols, respiratory and muscular,

Table V. Postoperative 6-minute walking test values and the difference of each group between preoperative and postoperative period ( $\mathrm{m}$ )

\begin{tabular}{|c|c|c|c|c|}
\hline $\begin{array}{l}\text { Group R } \\
(n=34)\end{array}$ & $\begin{array}{l}\text { Group R + M } \\
(n=34)\end{array}$ & $\begin{array}{l}\text { Group C } \\
(n=34)\end{array}$ & $P$-value & $\begin{array}{l}\text { Loss difference }(\mathrm{m}) \text { between preoperative } \\
\text { and postoperative }\end{array}$ \\
\hline \multirow[t]{3}{*}{$269.6 \pm 106$} & $375.0 \pm 92.7$ & $205.3 \pm 89.0$ & $<0.0001^{*}$ & 79 (group R) \\
\hline & & & $0.009^{\star \star}$ & 40 (group $R+M)$ \\
\hline & & & $<0.0001^{\star \star *}$ & 94 (control group) \\
\hline
\end{tabular}

${ }^{\star} P=$ significant (group $\mathrm{R}$ vs. group $\mathrm{R}+\mathrm{M}$ ); ${ }^{* *} p=$ significant (group $\mathrm{R}$ vs. group $\mathrm{C}$ ); ${ }^{* \star *} p=$ significant (group $\mathrm{R}+\mathrm{M}$ vs. control group). 
the one that gave the greatest benefits was the respiratory protocol, probably because it favored greater beneficial effects on the respiratory function, which, as expected, is usually compromised after sternotomy.

Several published studies have highlighted advantages of faster functional recovery after cardiac surgery through the preoperative muscle and musculoskeletal exercise protocols [20-26]. In our study, the muscle exercise protocol, performed in only one group of patients, showed a greater motor capacity immediately before the intervention (i.e. more than 100 meters) (Table II), but, above all, less reduced tolerance to movement after surgery in comparison with group $\mathrm{R}$ and the control group (Table III). In particular, its benefit in terms of a better preserved residual motor capacity in the postoperative period was observed in comparison with the control group.

Finally, the length of postoperative in-hospital stay observed in both treated groups was significantly shorter in comparison with that of the control groups. The hospitalization beyond the average of six postoperative days was related to the fact that the patients underwent routine postoperative checks (chest X-ray, blood samples with chemical and blood count control), which, regardless of the respiratory or walking autonomy obtained, were performed up to normalization of the various parameters (e.g. white blood cell count, serum creatinine level, glycemia) and to the control of the sternal wound healing before being transferred to continue their cardiorespiratory rehabilitation in specific centers.

The main limitations of the study are related to the fact that it is a retrospective one, not randomized, and that the sample of patients analyzed was limited. Furthermore, there was a higher incidence of previous smokers in the control group than in the two treated groups of patients. However, in contrast, in the $R+M$ group there was a greater incidence of active smoking patients. And therefore, from the available data, we could think that this statistical difference did not globally influence the results obtained in our analysis.

This study could indicate that the performance of the rehabilitation program, respiratory and motor, before elective cardiac surgery should be recommended to all patients when possible, in order to make the postoperative period less traumatic, and to facilitate a faster functional recovery. In fact, both integrated respiratory and motor preoperative physiotherapy can yield better results than those observed in the control group, playing an essential role in accelerating the recovery of respiratory and musculoskeletal function.

\section{Conclusions}

A substantial benefit can be observed in patients preoperatively treated with respiratory and motor physiotherapeutic protocols, either immediately before or after cardiac surgery. In all patients, as expected, there was a decrease in the postoperative period of the measured values due to the surgical trauma and full sternotomy, but groups $R$ and $R+M$ achieved overall better results in the forced expira-

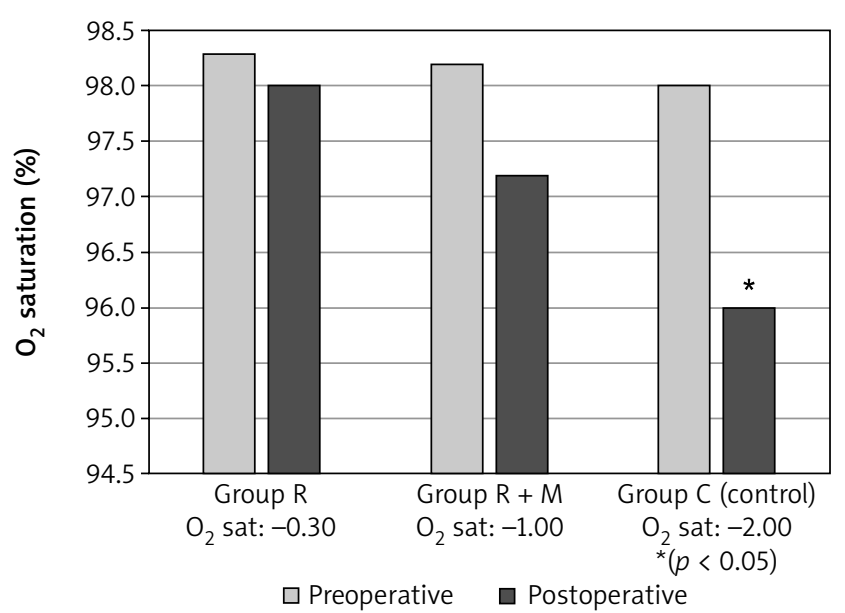

Figure 1. Oxygen arterial saturation, expressed in percent, in blood; comparison between groups $R, R+M, C$, with the reported delta difference between postoperative and preoperative period

tory test, in the control of respiratory values in the blood gas analysis, and in their motor activity.

\section{Disclosure}

Authors report no conflict of interest.

\section{References}

1. Leon AS, Franklin BA, Costa F, et al.; American Heart Association; Council on Clinical Cardiology (Subcommittee on Exercise, Cardiac Rehabilitation, and Prevention); Council on Nutrition, Physical Activity, and Metabolism (Subcommittee on Physical Activity); American association of Cardiovascular and Pulmonary Rehabilitation. Cardiac rehabilitation and secondary prevention of coronary heart disease: an American Heart Association scientific statement from the Council on Clinical Cardiology (Subcommittee on Exercise, Cardiac Rehabilitation, and Prevention) and the Council on Nutrition, Physical Activity, and Metabolism (Subcommittee on Physical Activity), in collaboration with the American association of Cardiovascular and Pulmonary Rehabilitation. Circulation 2005; 111: 369-376.

2. Hulzebos EH, Van Meeteren NL, De Bie RA, et al. Prediction of postoperative pulmonary complications on the basis of preoperative risk factors in patients who had undergone coronary artery bypass graft surgery. Phys Ther 2003; 83: 8-16.

3. da Costa Torres D, Dos Santos PM, Reis HJ, et al. Effectiveness of an early mobilization program on functional capacity after coronary artery bypass surgery: a randomized controlled trial protocol. SAGE Open Medicine 2017; 4: 2050312116682256.

4. Rawat N, Yang T, Ali KJ, et al. Two-state collaborative study of a multifaceted intervention to decrease ventilator-associated events. Crit Care Med 2017; 45: 1208-1215.

5. Moradian ST, Najafloo M, Mahmoudi H, Ghiasi MS. Early mobilization reduces the atelectasis and pleural effusion in patients undergoing coronary artery bypass graft surgery: a randomized clinical trial. J Vasc Nurs 2017; 35: 141-145.

6. Stammers AN, Kehler DS, Afilalo J, et al. Protocol for the PREHAB study-preoperative rehabilitation for reduction of hospitalization after coronary bypass and valvular surgery: a randomised controlled trial. BMJ Open 2015; 5: e007250.

7. Achttien RJ, Staal JB, van der Voort S, et al.; Practice Recommendations Development Group. Exercise-based cardiac rehabilitation in patients with coronary heart disease: a practice guideline. Neth Heart J 2013; 21: 429-438.

8. Nardi P, Pellegrino A, Pisano C, et al. The effect of preoperative respiratory physiotherapy and motor exercise in patients undergoing elective cardiac surgery: short-term results. Kardiochir Torakochirurgia Pol 2019; 16: 81-87.

9. Brooks D, Solway S, Gibbons WJ. ATS statement: guidelines for the six-minute walk test. Am J Respir Crit Care Med 2003; 167: 1287. 
10. Wilson RC, Jones PW. Long-term reproducibility of Borg scale estimates of breathlessness during exercise. Clin Sci 1991; 76: 277-282.

11. Sehlin M, Ohberg F, Johansson G, Winsö O. Physiological responses to positive expiratory pressure breathing: a comparison of the PEP bottle and the PEP mask. Respir Care 2007; 52: 1000-1005.

12. Lellouche F, Delorme M, Bussières J, Ouattara A. Perioperative ventilatory strategies in cardiac surgery. Best Pract Res Clin Anaesthesiol 2015; 29: 381-395.

13. Arthur HM, Daniels C, McKelvie R, et al. Effect of a preoperative intervention on preoperative and postoperative outcomes in low-risk patients awaiting elective coronary artery bypass graft surgery. A randomized, controlled trial. Ann Intern Med 2000; 133: 253-262.

14. Cavenaghi S, Ferreira LL, Marino LH, Lamari NM. Respiratory physiotherapy in the pre and postoperative myocardial revascularization surgery. Rev Bras Circ Cardiovasc 2011; 26: 455-461.

15. Valkenet K, Trappenburg JC, Hulzebos EH, et al. Effects of a pre-operative home-based inspiratory muscle training programme on perceived healthrelated quality of life in patients undergoing coronary artery bypass graft surgery. Physiotherapy 2017; 103: 276-282.

16. Leguisamo CP, Kalil RA, Furlani AP. Effectiveness of a preoperative physiotherapeutic approach in myocardial revascularization. Braz J Cardiovasc Surg 2005; 20: 134-141.

17. Waite I, Deshpande R, Baghai M, et al. Home-based preoperative rehabilitation (prehab) to improve physical function and reduce hospital length of stay for frail patients undergoing coronary artery bypass graft and valve surgery. J Cardiothorac Surg 2017; 12: 91.

18. Shakouri SK, Salekzamani Y, Taghizadieh A, et al. Effect of respiratory rehabilitation before open cardiac surgery on respiratory function: a randomized clinical trial. J Cardiovasc Thorac Res 2015; 7: 13-17.
19. Hulzebos EH, Smit Y, Helders PP, van Meeteren NL. Preoperative physical therapy for elective cardiac surgery patients. Cochrane Database Syst Rev 2012; 11: CD010118.

20. Cordeiro A, Melo T, Neves D, et al. Inspiratory muscle training and functional capacity in patients undergoing cardiac surgery. Braz J Cardiovasc Surg 2016; 31: 140-144.

21. Valkenet $\mathrm{K}$, de Heer F, Backx FJ, et al. Effect of inspiratory muscle training before cardiac surgery in routine care. Phys Ther 2013; 93: 611-619.

22. Mans CM, Reeve JC, Elkins MR. Postoperative outcomes following preoperative inspiratory muscle training in patients undergoing cardiothoracic or upper abdominal surgery: a systematic review and meta analysis. Clin Rehabil 2015; 29: 426-438.

23. Katsura M, Kuriyama A, Takeshima T, et al. Preoperative inspiratory muscle training for postoperative pulmonary complications in adults undergoing cardiac and major abdominal surgery. Cochrane Database Syst Rev 2015; 10: CD010356.

24. Hirschhorn AD, Richards D, Mungovan SF, et al. Supervised moderate intensity exercise improves distance walked at hospital discharge following coronary artery bypass graft surgery: a randomised controlled trial. Heart Lung Circ 2008; 17: 129-138.

25. Hirschhorn AD, Richards DA, Mungovan SF, et al. Does the mode of exercise influence recovery of functional capacity in the early postoperative period after coronary artery bypass graft surgery? A randomized controlled trial. Interact Cardiovasc Thorac Surg 2012; 15: 995-1003.

26. Kendall F, Oliveira J, Peleteiro B, et al. Inspiratory muscle training is effective to reduce postoperative pulmonary complications and length of hospital stay: a systematic review and meta-analysis. Disabil Rehabil 2018; 40: 864-882. 